\title{
Where to hike? Mobile application for guiding tourists in the Bükkalja Region, Hungary
}

\author{
Márton Pál ${ }^{\mathrm{a}, \mathrm{b}}$ *, Zoltán Túri ${ }^{\mathrm{c}}$, Marcell Lavaj ${ }^{\mathrm{d}}$ \\ ${ }^{a}$ ELTE Eötvös Loránd University, Doctoral School of Earth Sciences, marchello@ map.elte.hu \\ ${ }^{b}$ ELTE Eötvös Loránd University, Faculty of Informatics, Institute of Cartography and Geoinformatics \\ ${ }^{c}$ University of Debrecen, Faculty of Science and Technology, Department of Physical Geography and Geoinformatics, \\ turi.zoltan@science.unideb.hu \\ ${ }^{d}$ University of Debrecen, Faculty of Science and Technology, Department of Physical Geography and Geoinformatics, \\ lavajmarci97@gmail.com \\ * Corresponding author
}

\begin{abstract}
Hiking is one of the most popular outdoor sports activities in Hungary. Despite not having many mountainous areas, a wide network of hiking trails crosses the country's landscapes. As online tourist maps and thematic mobile applications become more and more popular among hikers, the role of paper-based, analogue tourist maps decreases. However, no thematic application has been issued that contains detailed surveyed (or crowdsourced) data on attractions or the natural circumstances (coverage, difficulty) for a certain area in Hungary yet. Nature tourism in the Bükkalja Region, Hungary is mostly based on geological-geomorphological features that are completed with cultural facilities. The length of the hiking trail system is more than $370 \mathrm{~km}$ in the examined $354 \mathrm{~km}^{2}$ large sample area. We have developed an OS mobile application that offers guidance for tourists based on four basic pillars: the physical condition of the trails, the attractions along a trail, dangerous trail segments and hiking trail marking quality. These pillars are visualized with an OpenLayers-based online map. The result is a multi-purpose smartphone application. Its main aim is to offer a planning platform for tourists by examining the difficulty of the trails and designating the attractions to visit. There is information on the most important attractions of the area: cultural and geoscientific sites are also presented. We also encourage users to report changes to the map data content via the crowdsourcing menu. These comments and remarks are continuously checked for validity and the database is modified with the use of them.
\end{abstract}

Keywords: hiking, Android, mobile application, GIS mapping, OpenLayers

\section{Introduction}

Hiking is an important and popular outdoor activity all over the world. People discover new places or routes in the natural environment due to various reasons: they consider hiking as a sporting activity, as a good way to find and explore interesting ecological, geologicalgeomorphological and/or cultural facilities or just as a mean to spend their free time in calm and stressless circumstances (Benkhard 2018, Vizkelety 1986).

In Hungary, many guides and hiking maps have been issued since the beginning of organised tourism activity in the second half of the $19^{\text {th }}$ century (Hajdú \& Pál 2021; Strömpl 1931). Their main aim was to give aid to tourists when planning their routes before or during the hike: what to visit and which way to choose. Hiking maps have undergone great changes since that time (Hajdú \& Pál 2021): paper maps with proper visual solutions and representations are complemented or substituted by digital smartphone map applications (e.g., MTSZ 2021).

However, none of these applications gives hints about the physical attributions of the trails, though these data and information would help tourists with various endurance levels and abilities. We have planned a smartphone application dedicated to the Bükkalja Region, Hungary, that we chose as a sample area. This app examines the area's hiking trails and tourism infrastructure based on four pillars:

- What is the physical condition of the trails (walkability, steepness, path width)?

- What attractions can a visitor find when choosing a certain trail?

- Are there any dangerous trail parts (e.g., mostly slippery, or rocky areas)?

- What is the quality of the hiking trail marking (traceability, mistakes)?

Our main aim was to build an online map within an opensource smartphone application that is compatible with many mobile devices and can be used on the field. OpenLayers for the cartographic-GIS representation and Android as the solution for the application framework proved to be the most beneficial chance. We considered important beside the map and its thematic layers that the application could give information on the important sights and tourism infrastructure facilities of the sample area.

\section{The Bükkalja Region}

The Bükk Mts has the highest average altitude among the Hungarian mountains. It got its name from the 'bükk' (beech) tree (Fagus silvatica). Its highest peak is Istállós Stone $(959 \mathrm{~m})$. It is an important karst area with many caves and interesting limestone formations. The Bükk 
Highland is a 'treasure chest' of karstic phenomena: it is full of smaller and dolines and sinkholes (Dövényi 2012).

Our designated sample area (Fig. 1), the western part of the Bükkalja region is in the SW part of the Bükk Mts, near the city of Eger. Its area is $353.7 \mathrm{~km}^{2}$ and incorporates 4 settlements from Borsod-Abaúj-Zemplén County (Bogács, Bükkzsérc, Cserépfalu and Szomolya) and 5 from Heves County (Eger, Felsőtárkány, Noszvaj, Ostoros and Szarvaskö). The Bükkalja was formed when the Bükk Mts lifted in Miocene. During this process, some parts broke these fault lines are the current valleys of creeks and small rivers. However, these southern foothills of the overwhelmingly carbonaceous Bükk Mountains are mostly built up of silicic volcanic rocks (tuffs and ignimbrites with rhyolitic composition). The most significant remnants of this activity are the Beehive Rocks ('Kaptárkövek') that are the important geological and cultural heritage of the region. During the Ice Ages, the forms of the area were eroded and rounded (Baráz 2015).
The area is naturally covered with oak woods that become sparser from North to South. We can also find beech woods in higher altitudes and even small pinewood patches that were planted. Agriculture is an important sector in the region, especially because the surroundings of Eger belong to the Eger Wine Region. But the 600-700 mm of precipitation and the southern exposure are suitable for most agricultural activities that are present in Hungary (Dövényi 2012, Sütö et al. 2021).

The tourism of the area is concentrated on Eger, which is in the western part of our sample area. It offers a wide variety of cultural (museums, the castle, the palace of the archbishop) and natural free time activities (Nagy-Eged, spas). The Bükk National Park (and the Bükk Region Geopark within this organisation) is responsible for the protection of the geoheritage and ecological values of the area. The most important sights of the area are connected to Szarvaskő (Castle Hill), Szomolya (Beehive Stones), Cserépfalu (Hór Valley), and Noszvaj (Síkfökút).

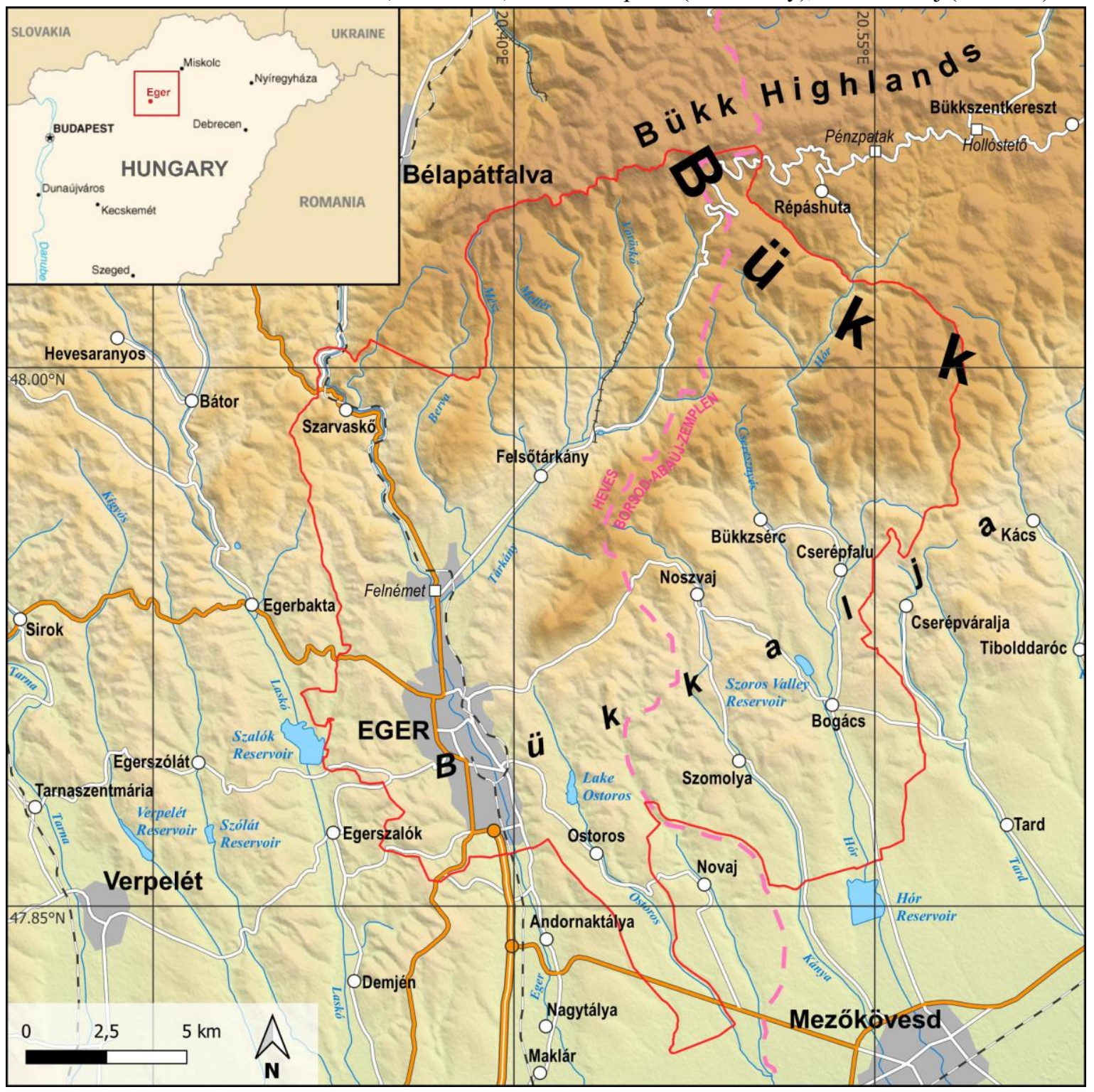

Figure 1. The surroundings of the Bükkalja Region. Our sample area is within the red borders. 


\section{Thematic data of the area's hiking trails}

The total length of hiking trails in the sample area is $421.5 \mathrm{~km}$. The surroundings of all these trails were examined in order to detect tourism infrastructure elements, their condition, and even the physical attributions of the trails themselves. The combination of the trail and other built infrastructure data were integrated into the application. These two information types can be well distinguished - data on trails are connected to line features while data on tourism infrastructure are connected to point features. We have recorded every feature in a geodatabase and provided information about their current condition using a special form edited for this purpose (Lavaj et al. 2019).

\subsection{Tourism infrastructure elements}

Three main attributes were recorded for every tourism infrastructure feature: an ID, the type of the object and the current visible condition of the object.

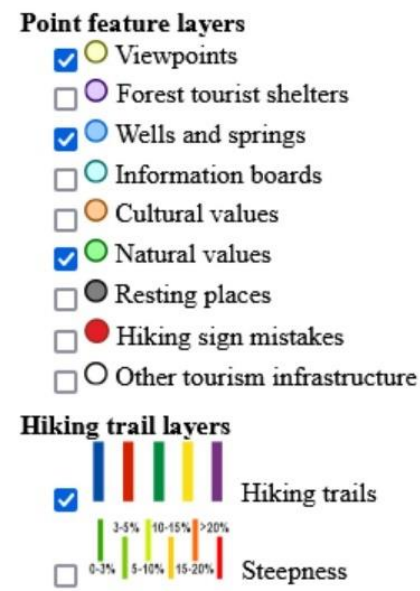

Figure 2. An excerpt of the legend of point and line features.

We have distinguished the following object types (Fig. 2):

- Forest tourist shelters: campsites or other suitable places for tourism accommodation.

- Resting places: sites with benches, rain protection, fireplaces, dustbins, and small buffets or restaurants outside a settlement.

- Viewpoints: natural and manmade sites were also recorded. An additional attribute is the angle of view.

- Maintained wells and springs.

- Information boards: road signs, boards of educational trails, geological and ecological educational panels, and others.

- Natural values: within this group unmaintained springs, characteristic trees helping orientation, lakes, geological outcrops, and caves were distinguished.

- Cultural values: various manmade objects form this feature set (e.g., castles, churches, or monuments).
- Other tourism infrastructure: these objects were not classified to other groups, e.g., hunter stands or stamps of the National Blue Trail.

- Hiking sign mistakes: this object type usually refers to junctions, where it is problematic to determine the continuation of the trail. The main causes of this can be aged signs, vegetationcovered signs or even the lack of signs.

The condition of these objects was recorded based on the following scale:

- new or well-maintained,

- damaged but usable,

- critical and unusable.

Besides these, a 'notation' field was also defined in the geodatabase to provide any other necessary information (e.g., the keywords of an information board).

\subsection{Hiking trail data}

Besides the sign of each hiking trail, five different thematic attributes were recorded for every line feature as a result of fieldwork. Only the 'coverage' attribute was defined using the CORINE database (EEA 2018). These are the followings (Fig. 2):

- The steepness of the hiking trail. It is in connection with the hikers' physical condition. We have defined six categories of difficulty (Dombay \& Magyari-Sáska 2006): very easy (0$3 \%)$, easy (3.1-5\%), moderate (5.1-10\%), difficult (10.1-15\%), very difficulty (15.1-20\%), and extremely difficult (above 20\%).

- The difficulty level of walking on a trail. We have defined three categories: easy, moderate, and difficult.

- The difficulty level of following hiking trails: easy, moderate, and difficult.

- Coverage type. The CORINE dataset determines this attribute for each line feature within a land cover polygon. The categories are the same as in the base data (EEA 2018).

- Width of the trails. We defined four categories: 1 - suitable for walking (trails), 2 - forest roads suitable for vehicles too, 3 - wide and maintained forest roads, 4 - paved (asphalt or concrete) roads.

If a line feature was omitted during fieldwork or no appropriate data was recorded, it got a unique attribute in the case of all five thematic factors. These lines and their recorded information were also considered as a geodatabase.

\section{The Bükkalja application}

After the building of the distinct point-feature and linefeature geodatabases, we have styled each category. To visualize the data for the broad public, we decided to combine web cartography (web GIS) and the Android operating system. 
The application building consisted of two main steps: creating a properly styled web map (using HTML, CSS and OpenLayers JS), and a framework application in the Android Studio IDE (Integrated Development Environment).

There are several ways to visualise spatial data in an Android environment, but the most easily maintainable and upgradeable solution is the 'WebView' object of the Android Studio. Developers can put smartphonecompatible webpages into this object meaning that the maintenance of the map content does not need the update of the entire application in case of Internet connection. It also means that the map data are stored on a server - so the size of the app remains quite small. It is also possible to create an offline 'WebView' as this object is able to handle HTML files. In the case of this solution, the HTML and the used data files are needed to be on the mobile device that occupies more physical storage.

\subsection{Creating a web map for the application}

A good web GIS solution is OpenLayers that is an opensource JavaScript library that makes it possible to visualise spatial data in a web browser (Fig 3).

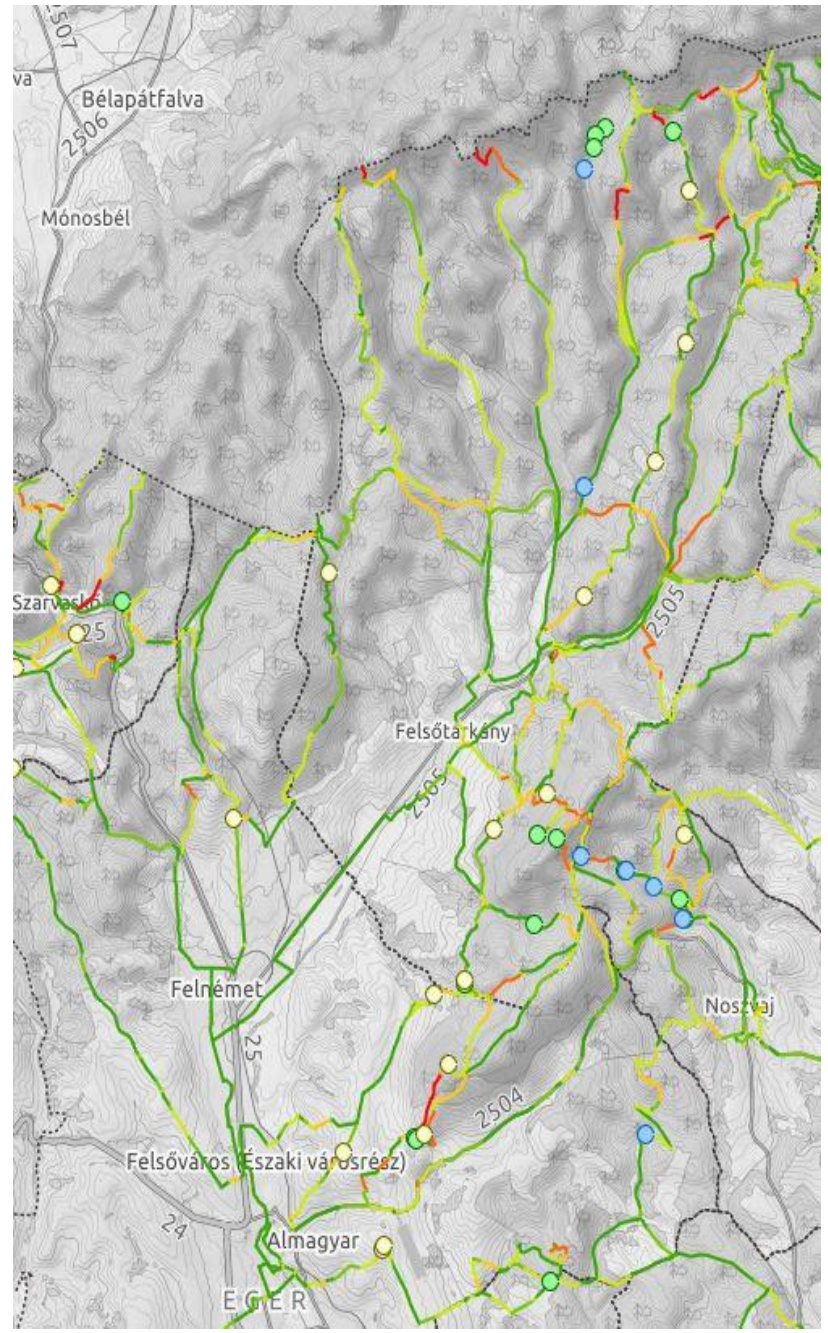

Figure 3. Steepness data for hiking trails and various point features visualized using OpenLayers.
A classic web GIS project is built up by the use of three different programming languages (that can be written into a single file): HTML (HyperText Markup Language) defines the main elements of the page, CSS (Cascading Style Sheets) defines the style of the HTML elements and JS (JavaScript) for scripting (including the OpenLayers library).

Our webpage is built up by a large map element (Fig. 3), a legend (Fig. 2), and a GPS window. The two latter objects are clickable and hidable.

The GPS window uses the position data of the device (either PC or smartphone): we can track our movement on the field with this function.

Eventually, the legend is a clickable layer selector: by using this window, we can choose what thematic layer we would like to see. Point and line feature layers can be examined in parallel. In this window, users can choose from a set of base maps, and they can switch on or off settlement boundaries. The role of the base map is quite important: it should provide enough information for orientation, but it should be also legible if we visualise the thematic data on it. Regarding these factors, we decided to apply a greyscale Thunderforest Landscape (a restyled OpenStreetMap-based map tile provider) map.

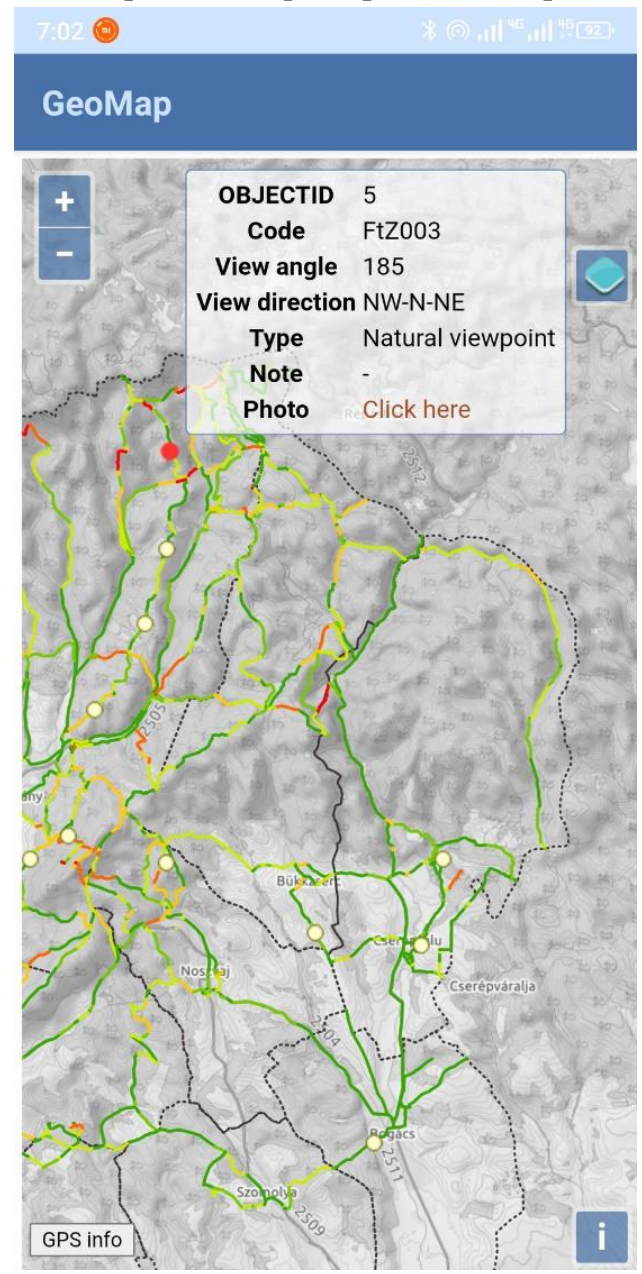

Figure 4. If we click on a feature in the 'GeoMap', we can read the information on the corresponding object. In the case of some sights, a photo is also attached. 


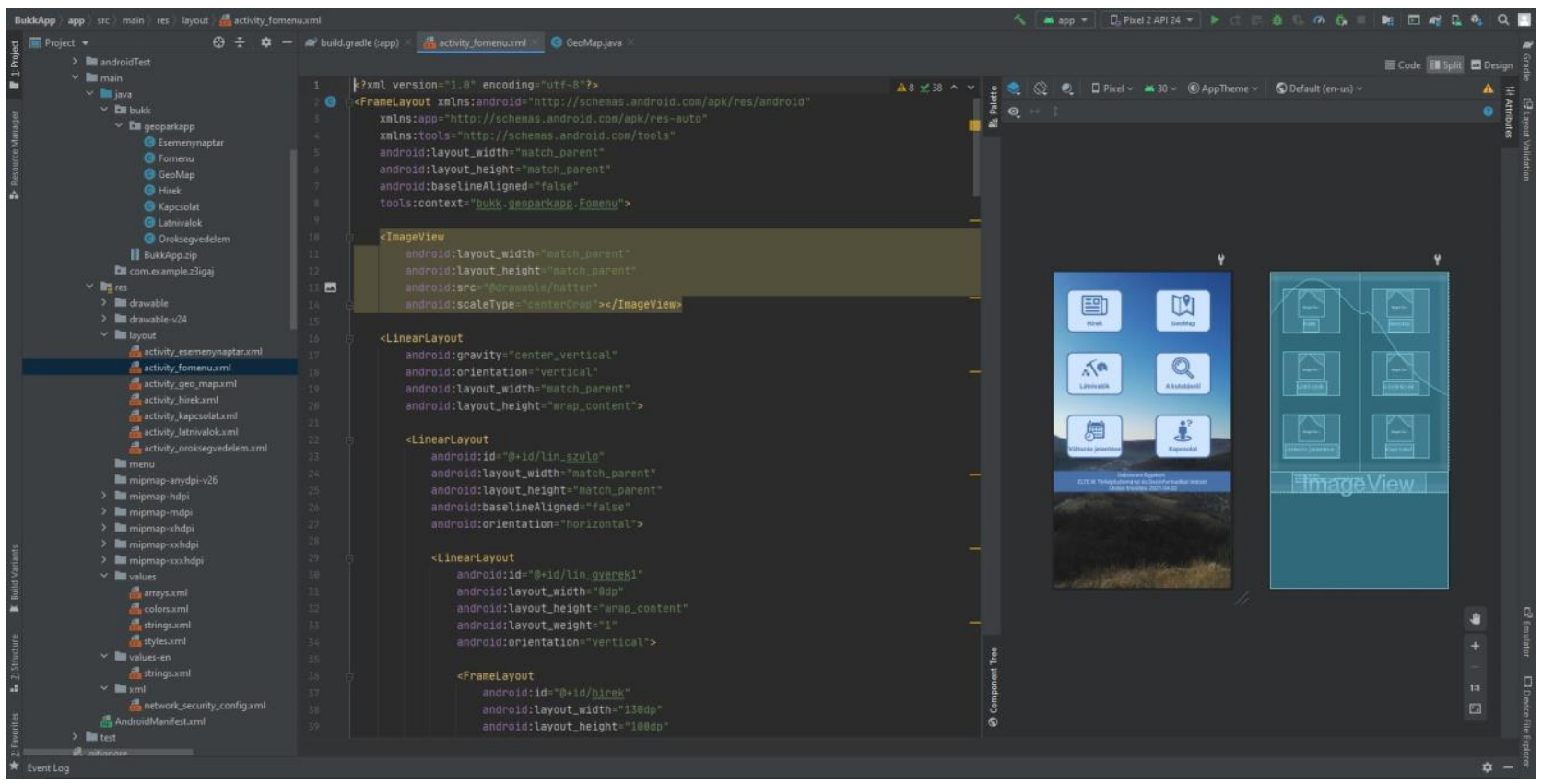

Figure 5. The main menu of the application in Android Studion during programming.

An important feature of this page is that by clicking on a thematic feature of a layer, its attributions can be queried. It has large importance on the field as every necessary information can be reached by clicking on the desired feature (Fig. 4).

\subsection{Creating the application framework in Android Studio}

The building of any mobile application consists of two main steps: 1) to define the outlines (objects) of the application window and 2) to program the defined objects. Android Studio uses XML for creating window objects and Java (or Kotlin) for programming (Fig. 5).

Our application has six window pages and the main menu (Fig. 6). In the 'News' window users can read fresh information and news about the area. The 'GeoMap' window includes the 'WebView' object of the previously created OpenLayers map. The 'Research work' window gives information about the scientific background of the application, while the 'Contact' page includes access to the developers.

The 'Submit changes' window has a crowdsourcing aim. It contains a form: users can submit any changes that they see or experience in the field. These crowdsourced data are continuously built into the application - so the maintenance is not restricted to the developers but to the users too.

Android Studio offers to make applications in various languages: we decided to create a Hungarian and an English version.

\section{Discussion and conclusion}

The main aim of this research was to create a widely and easily useable tool for tourists for field orientation and additional information about hiking trails and tourism infrastructure. By fieldwork and using online data sources we were able to produce a geodatabase. We give information about the available tourism infrastructure (e.g., shelters, resting places, drinking water, information boards) and their physical condition. Various hiking trail attributions were also presented, like steepness, coverage, and trail width. The database was visualized and styled with the OpenLayers web GIS solution. Android Studio made it possible to program an application that can visualise and present our data to the broader public.

The possible weakness of the application is the need for an internet connection in the field. This may cause some problems in hidden places or deep valleys. A future plan is to create an offline application by putting all data files and an offline base map on the mobile device too. Another improvement can be the extension of the sample area: other parts of the Bükk Mts also have many natural and cultural values that can be presented this way.

This study and the application are initial applications of 1) earth scientific data, 2) crowdsourcing solutions and 3) very detailed field information for tourists. The continuation of this work even in other areas could ensure the growing need of tourists for current spatial and infrastructural information.

\section{Acknowledgements}

Marcell Lavaj was supported by the Hungarian Ministry of Innovation and Technology's ÚNKP-20-2 New National Excellence Program.

\section{References}

Baráz, Cs. (2015). Beehive Rocks in the Bükk Foothills: A Landscape Born in Fire. In: Lóczy, D. (ed., 2015). Landscapes and Landforms of Hungary. Springer. DOI: 10.1007/978-3-319-08997-3_24.

Benkhard, B. (2018). Determination of tourist flow patterns in a low mountain study area. Tourism \& Management Studies, 14(3):19-31 DOI: https://doi.org/10.18089/tms.2018.14302 
Dombay, I., Magyari-Sáska, Zs. (2006). Hegyvidéki turistautak elemzése GIS rendszerek segítségével. III. Hungarian Geographic Conference 2006.09.6-8., MTA FKI, Budapest, Hungary. http://geography.hu/mfk2006/pdf/Dombay\%20Istv\%E1 n.pdf.

Dövényi, Z. (ed., 2012). Geography of the Carpathian Basin (A Kárpát-medence földrajza). Academic Press, Budapest.

European Environment Agency (2018). Corine Land Cover 2018 seamless vector data, Kopenhagen, Denmark.

Hajdú, E., Pál, M. (2021). The digital reconstruction of hiking trail system evolution in the Mátra Mts, Hungary. 15th ICA Conference Digital Approaches to Cartographic Heritage, Conference Proceedings, pp. 4356.

Lavaj, M., Nagy, Á., Tóth, L. (2019). Az Egri borvidék természetjáró adottságainak felmérése turisztikai döntéstámogató rendszer megalapozásához. National Scientific Students' Associations Conference, manuscript, Eger, Hungary.

Magyar Természetjáró Szövetség - Hungarian Tourist Association (2021). Természetjáró app. Online: https://www.termeszetjaro.hu/hu/mobile-app.html. Last access: 08.11.2021.

Strömpl, G. (1931). Hiking maps of the State Mapping Institute (Az Állami Térképészet Turistatérképei), Cartographic Bulletin (Térképészei Közlöny), pp. 212216.

Sütő, L., Balogh, S., Novák, J.T., Homoki, E., Rózsa, P. (2021). A historic geographic approach to the anthropic disturbance in the Bükk region. Landscape \& Environment, 15(1):58-65. https://doi.org/10.21120/LE/15/1/8

Vizkelety, L. (ed., 1986). General knowledge on tour guiding (A túravezetés általános ismeretei). Hungarian Tourist Association, Budapest, Hungary. 